Journal of Telenursing (JOTING)

Volume 3, Nomor 1, Juni 2021

e-ISSN: 2684-8988

p-ISSN: 2684-8996

DOI: https://doi.org/10.31539/joting.v3i1.2157

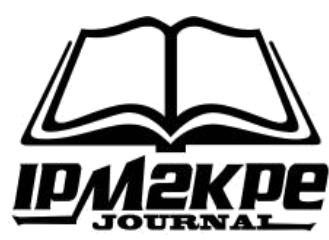

\title{
POLA SHIFT PERAWAT DI MASA PANDEMI COVID-19
}

\author{
Kartika Mawar Sari Sugianto ${ }^{1}$, Rr. Tutik Sri Hariyati ${ }^{2}$, Annisa Rahmi Galleryzki ${ }^{3}$ \\ Universitas Indonesia ${ }^{1,2,3}$ \\ rrtutik@yahoo.com ${ }^{2}$
}

\begin{abstract}
ABSTRAK
Penelitian ini bertujuan untuk mengetahui pola shift yang digunakan rumah sakit selama masa pandemi. Desain penelitian menggunakan sistematik review melalui database online seperti Science direct, EBSCOhost, Scopus, ProQuest, Google Scholar dan sumber pencarian lainnya. Proses pemilihan artikel menggunakan metode PRISMA. Jumlah artikel yang diperoleh adalah 795, kemudian hanya 11 yang digunakan dalam tinjauan ini. Hasil penelitian ini menunjukkan bahwa pola shift selama masa pandemi meliputi (1) 12 jam per shift; (2) 6 jam per shift; (3) 4-8 jam dengan pembagian waktu dalam shift; (4) pola 7-7-10; (5) jadwal kerja fleksibel, interval pendek; (6) tiga tahap rotasi dan rencana karantina 14 hari. Simpulan, pola shift 12 atau 6 jam tanpa istirahat berdampak tidak baik bagi kesehatan perawat, sedangkan pola shift lain cenderung memperhatikan kesehatan dan keselamatan perawat di masa pandemi.
\end{abstract}

Kata Kunci: Pandemi COVID-19, Pola Shift Perawat

\section{ABSTRACT}

This study aims to determine the shift patterns used by the hospital during the pandemic. The research design uses systematic reviews through online databases such as Science Direct, EBSCOhost, Scopus, ProQuest, Google Scholar, and other search sources. The article selection process uses the PRISMA method. The number of articles obtained was 795, and then only 11 were used in this review. The results of this study indicate that the shift pattern during the pandemic period includes (1) 12 hours per shift; (2) 6 hours per shift; (3) 4-8 hours divided into shifts; (4) pattern 7-7-10; (5) flexible work schedules, short intervals; (6) three stages of rotation and a 14 day quarantine plan. In conclusion, the 12 or 6 hour shift pattern without a break is not suitable for nurses' health, while other shift patterns tend to pay attention to the health and safety of nurses during a pandemic.

Keywords: Pandemic COVID-19, Nurse Shift Pattern

\section{PENDAHULUAN}

Peningkatan kasus COVID-19 menyebabkan terjadinya perubahan layanan di rumah sakit salah satunya adalah perubahan alur kerja perawatan, khususnya di ruang isolasi (Gao et al., 2020). Menurut Liang (2020) dalam melakukan pelayanan keperawatan, jam kerja perawat dibatasi maksimal 4 jam. Hal ini dilakukan untuk mengurangi paparan infeksi. Penggunaan alat pelindung diri (APD) selama kontak langsung dengan pasien menjadi tantangan tersendiri bagi perawat yang bertugas di 
ruang isolasi COVID-19. Perubahan lain yang terjadi yaitu pada penjadwalan perawat, hal ini dikarenakan rumah sakit mengalami kekurangan tenaga untuk menangani pasien COVID-19 (Al Thobaity \& Alshammari, 2020). Perawat yang bertugas di ruang isolasi berasal dari ruangan lain atau perawat magang sehingga harus dilakukan penyesuaian komposisi tenaga di dalam shift (Gao et al., 2020).

Perawat merupakan profesi yang paling rentan terpapar infeksi di masa pandemi, namun tetap harus memberikan pelayanan dengan melakukan kontak langsung kepada pasien dalam mengimplementasikan asuhan keperawatan (Huang et al., 2020). Beban kerja yang tinggi di masa pandemi mengakibatkan perawat rentan mengalami kelelahan, kecemasan dan depresi (Hu et al., 2020). Peran aktif perawat manager diperlukan agar kesehatan dan keselamatan perawat dapat dipertahankan.

Masalah ketenagaan sendiri merupakan tantangan besar bagi perawat manajer di masa pandemi COVID-19 di rumah sakit. Perawat manajer bertanggung jawab untuk mempertahankan rasio perawat-pasien dengan melakukan berbagai pengaturan kerja, misalnya dengan mobilisasi tenaga perawat dari unit lain baik sementara atau permanen kepada unit yang kekurangan tenaga (Gan, 2020). Paparan infeksi terhadap perawat menyebabkan ketidakstabilan jumlah tenaga di ruangan. Pengaturan penjadwalan dan pola shift diperlukan untuk pemanfaatan tenaga secara efektif dan efisien.

Studi literatur terkait pola shift perawat di masa pandemi masih belum banyak. Salah satu studi tentang pengalaman perawat di ruang isolasi adalah mengenai perawat yang lebih menyukai pola shift 4 jam (Gao et al., 2020). Namun pola tersebut tidak bisa dijadikan pilihan utama oleh pihak rumah sakit, sehingga diperlukan studi yang dapat memberikan informasi yang lebih lengkap mengenai pola shift di masa pandemi. Studi literatur ini bertujuan untuk mengetahui pola shift yang digunakan di rumah sakit selama masa pandemi dan manfaatnya bagi kesehatan dan keselamatan perawat.

\section{METODE PENELITIAN}

Desain yang digunakan adalah sistematik review dilakukan untuk mensintesis pola shift yang digunakan perawat selama masa pandemi. Tinjauan didasarkan pada pertanyaan penelitian "Apakah pola shift yang digunakan dapat mempertahankan kesehatan perawat selama masa pandemi?. Daftar periksa pelaporan sistematik review menggunakan Preferred Reporting Items for Systematic Reviews and Meta-Analysis (PRISMA) sebagai dasar untuk melaporkan tinjauan tersebut.

Pencarian sistematis dilakukan terhadap semua studi terkait tentang pola shift perawat selama masa pandemi COVID-19 menggunakan database online berikut: Science direct, EBSCOhost, Scopus, ProQuest, Google Scholar dan sumber pencarian lainnya dengan tahun pencarian yaitu 2020-2021 (disesuaikan dengan kondisi pandemi). Kata kunci yang digunakan terdiri dari "nurse scheduling", "nurse scheduling" and "pandemic, "nurse shift scheduling", "nurse shift" and "COVID", "nurse rostering" and "COVID", "nurse" and "work hour" and "pandemic". Proses pencarian menghasilkan total 795 artikel dengan filter yang digunakan adalah full text akses, satu tahun terakhir serta menggunakan Bahasa Inggris atau Indonesia.

Langkah berikutnya adalah melakukan penyaringan tahap pertama dengan mengeliminasi artikel yang memiliki kesamaan judul sehingga diperoleh 770 artikel. Selanjutnya dilakukan analisis kesesuaian judul dan abstrak dengan kriteria kelayakan dimana terdapat 717 artikel yang dieliminasi dan 4 artikel tidak mendapatkan full text. Sebanyak 35 artikel lengkap menjalani skrining tahap kedua dan diperoleh 12 artikel 
yang sesuai dengan kriteria inklusi. Selanjutnya dilakukan Quality appraisal, sehingga diperoleh 11 artikel yang digunakan dalam penelitian ini.

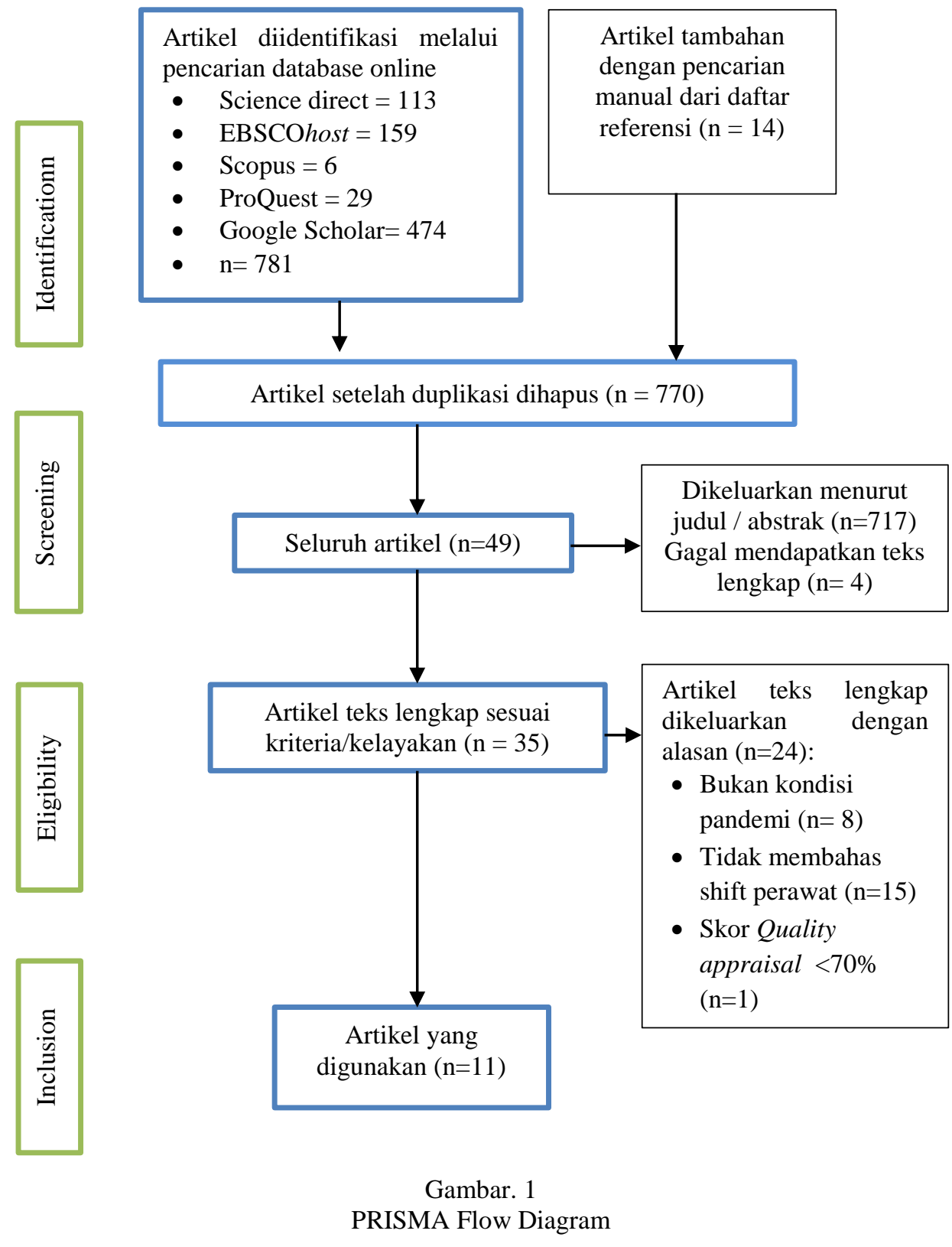

Kriteria inklusi ditentukan menggunakan kerangka PICO (P: population, $\mathrm{I}$ : interventions, $\mathrm{C}$ : comparisons, $\mathrm{O}$ : outcomes). P: studi memeriksa hasil pada perawat di rumah sakit (perawat manajer, perawat pelaksana, data perawat di dalam file); I: semua jenis pola shift perawat di rumah sakit selama masa pandemi; C:-; O: efek pola shift terhadap kesehatan atau keselamatan perawat. Kriteria ekslusi meliputi perawat di puskesmas, komunitas, dokter, tenaga kesehatan lainnya dan akademisi, tahun artikel kurang dari tahun 2020 dan menggunakan bahasa selain bahasa inggris dan Indonesia. Proses pemilihan studi dilakukan dengan 2 tahap. Tahap pertama, secara mandiri melakukan screening dengan melihat judul, abstrak dan membaca secara cepat isi artikel untuk melihat kesesuaian kriteria kelayakan. Studi yang tidak memenuhi kriteria inklusi dikeluarkan dari tinjauan. Selanjutnya, tahap kedua dengan melakukan review artikel 
yang telah lolos seleksi pada tahap 1 dengan menggunakan artikel lengkap. Perbedaan pendapat diselesaikan dengan virtual discussion oleh para penulis. Setelah pemilihan studi yang memenuhi kriteria inklusi, dilakukan penilaian kualitas data.

Penilaian kualitas data dilakukan oleh dua penulis (KMS dan ARG) menggunakan JBI Critical Appraisal (Joanna Briggs Institute, 2020). Terdapat pertanyaan dengan alokasi skor $\mathrm{Ya}=2$, Tidak $=0$, Tidak jelas $=1$. Keseluruhan pertanyaan memiliki hasil yang diubah dalam bentuk presentasi. Hasil menunjukkan skor artikel berada pada rentang 45-100\%. Setiap ketidaksepakatan antara peninjau diselesaikan melalui diskusi. Terdapat satu studi yang memiliki skor $<70 \%$ sehingga dikeluarkan.

\section{HASIL PENELITIAN}

Review dilakukan pada 11 artikel terkait pola shift perawat di rumah sakit selama masa pandemi COVID-19. Hasil review dapat dilihat pada tabel berikut ini:

Tabel. 1

Pola Shift di Masa Pandemi COVID-19

\begin{tabular}{|c|c|c|c|}
\hline Penulis & Pola Shift & Efek Pola Shift & $\begin{array}{l}\text { Jumlah } \\
\text { Artikel }\end{array}$ \\
\hline $\begin{array}{l}\text { Galehdar et al., } \\
\text { 2021; Holthof \& } \\
\text { Luedi, 2020; } \\
\text { Dall'Ora \& } \\
\text { Dahlgren, 2020; Al- } \\
\text { Dossary et al., } \\
\text { 2020; Kluger et al., } \\
2020\end{array}$ & $\begin{array}{c}12 \text { jam kerja } \\
\text { dalam setiap shift }\end{array}$ & $\begin{array}{l}\text { - Jam kerja yang panjang akan } \\
\text { menyebabkan perawat } \\
\text { kelelahan } \\
\text { - Jam kerja yang panjang dan } \\
\text { kerja lembur berisiko } \\
\text { meningkatkan cuti sakit dan } \\
\text { pergantian perawat yang } \\
\text { memperburuk situasi kelebihan } \\
\text { beban yang parah } \\
\text { - Penghematan staf yang } \\
\text { signifikan dengan membatasi } \\
\text { infeksi petugas kesehatan } \\
\text { - Bekerja selama 12 jam } \\
\text { memengaruhi kesejahteraan } \\
\text { mereka dan meningkatkan stres, } \\
\text { kelelahan dan kecemasan }\end{array}$ & 5 \\
\hline Liu et al., 2020 & $\begin{array}{l}6 \text { jam dalam } \\
\text { setiap shift }\end{array}$ & $\begin{array}{l}\text { - Model ini memastikan bahwa } \\
\text { staf perawat dapat memperoleh } \\
\text { istirahat yang cukup untuk } \\
\text { kualitas perawatan dan } \\
\text { keamanan perawat } \\
\text { - Mengurangi risiko tertular } \\
\text { seperti saat mengganti dan } \\
\text { melepas APD. }\end{array}$ & 1 \\
\hline $\begin{array}{l}\text { Apornak, 2021; } \\
\text { Gao et al., } 2020\end{array}$ & $\begin{array}{l}\text { Pola shift 4-8 jam } \\
\text { kerja (pagi, } \\
\text { siang/sore dan } \\
\text { malam) dengan } \\
\text { pembagian } \\
\text { periode waktu } \\
\text { dalam setiap shift }\end{array}$ & $\begin{array}{l}\text { - } \text { Memberikan kesempatan bagi } \\
\text { perawat untuk memenuhi } \\
\text { kebutuhan biologis dan } \\
\text { istirahat. } \\
\text { - } \text { Penyesuaian pola shift secara } \\
\text { dinamis sesuai penggunaan alat } \\
\text { pelindung diri dapat } \\
\text { meningkatkan kualitas } \\
\text { keperawatan dan kesejahteraan } \\
\text { fisik dan psikis perawat. }\end{array}$ & 2 \\
\hline Iswanto, 2020 & $\begin{array}{l}\text { Pola shift umum } \\
\quad(7-7-10)\end{array}$ & $\begin{array}{l}\text { - Istirahat dua hari setelah shift } \\
\text { malam dapat diberikan untuk }\end{array}$ & 1 \\
\hline
\end{tabular}




\begin{tabular}{|c|c|c|c|}
\hline Penulis & Pola Shift & Efek Pola Shift & $\begin{array}{l}\text { Jumlah } \\
\text { Artikel }\end{array}$ \\
\hline & & $\begin{array}{l}\text { mengembalikan pola hidup } \\
\text { sejak dini. } \\
\text { - Ketersediaan alat transportasi } \\
\text { pada waktu tertentu menjadi } \\
\text { pertimbangan dalam memulai } \\
\text { shift }\end{array}$ & \\
\hline $\begin{array}{l}\text { Poortaghi et al., } \\
2021\end{array}$ & $\begin{array}{l}\text { Jadwal kerja yang } \\
\text { fleksibel dengan } \\
\text { interval yang } \\
\text { lebih pendek dan } \\
\text { penataan ulang } \\
\text { tenaga kerja }\end{array}$ & $\begin{array}{l}\text { - Memberikan perawatan yang } \\
\text { lebih baik kepada pasien. } \\
\text { - Mencegah infeksi lebih lanjut } \\
\text { diantara staf. }\end{array}$ & 1 \\
\hline $\begin{array}{c}\text { Kuppuswamy \& } \\
\text { Sharma, } 2020\end{array}$ & $\begin{array}{l}\text { Tiga tahap rotasi } \\
\text { dan rencana } \\
\text { karantina selama } \\
14 \text { hari. Lama } \\
\text { shift untuk ICU } \\
\text { COVID-19: shift } \\
6 \text { jam dengan } 1 \\
\text { jam } \text { overlapping } \\
\text { (4 shift), ruang } \\
\text { isolasi: } \text { shift } 12 \\
\text { jam (2 shift), unit } \\
\text { non-COVID-19: } \\
\text { shift } 8 \text { jam (3 } \\
\text { shift) }\end{array}$ & $\begin{array}{l}\text { - Sistem yang dirancang untuk } \\
\text { mengalokasikan } \\
\text { menjadwalkan tenaga kerja } \\
\text { secara efisien selama pandemi. } \\
\text { Tujuannya adalah untuk } \\
\text { kesehatan dan keselamatan } \\
\text { perawat. }\end{array}$ & 1 \\
\hline
\end{tabular}

Hasil analisis pada tabel 1 menunjukkan bahwa selama masa pandemi perawat menggunakan pola shift yang berbeda. Secara umum, hasil studi menegaskan bahwa pola shift yang digunakan perawat di rumah sakit selama masa pandemi memiliki efek terhadap kesehatan perawat.

\section{PEMBAHASAN}

Perawat sebagai garda terdepan dalam memberikan pelayanan kesehatan di rumah sakit selama masa pandemi COVID-19 mengalami peningkatan beban kerja sebagai akibat meningkatnya jumlah pasien COVID-19 di rumah sakit. Penyesuaian jam kerja secara dinamis dan pengelolaan pola shift harus dilakukan terkait beberapa hal seperti penggunaan alat pelindung diri; kebutuhan fisik dan emosional perawat; kebutuhan keselamatan dan intensitas kerja perawat (Zhang et al., 2020). Berdasarkan review studi didapatkan bahwa rumah sakit menerapkan beberapa pola shift perawat yang berbeda.

Pola shift 12 jam paling banyak digunakan oleh rumah sakit terkait adanya kekurangan tenaga dan alat pelindung diri. Pola tujuh shift 12 jam dengan 7 hari libur di masa pandemi menunjukkan penghematan staf yang signifikan dengan membatasi infeksi petugas kesehatan (Holthof \& Luedi, 2020). Namun dalam studi lain didapatkan bahwa pola shift 12 jam dapat berdampak tidak baik terhadap kesehatan perawat (Galehdar et al., 2021;Dall'Ora \& Dahlgren, 2020; Al-Dossary et al., 2020), bekerja selama 12 jam dalam satu shift tidak dianjurkan karena dapat mengakibatkan kelelahan dan stress (Suter et al., 2020). Oleh karena itu penting bagi rumah sakit untuk dapat menyesuaikan pola shift perawat yang tepat dengan situasi dan kondisi yang terjadi serta tetap mempertahankan upaya menjaga kesehatan perawat selama masa pandemi. 
Studi lainnya didapatkan rumah sakit menggunakan pola shift 6 jam, hal ini dilakukan untuk memastikan bahwa perawat dapat memperoleh istirahat yang cukup serta mendapatkan kualitas perawatan dan keamanan pada perawat di klinik demam atau bangsal isolasi serta mengurangi risiko tertular seperti saat mengganti dan melepas APD (Liu et al., 2020; Astuti \& Suyanto, 2020). Standar waktu kerja produktif seorang perawat adalah $80 \%$ (Andra \& Insmainar, 2018) dari total jam kerja dalam setiap shift, dengan kata lain waktu istirahat yang diperlukan adalah 20\%. Di masa pandemi COVID-19 perawat memerlukan waktu istirahat yang cukup untuk menjaga kualitas kesehatannya. Perawat yang bertugas di ruang isolasi COVID-19 tidak disarankan bekerja lebih dari empat jam untuk mencegah kerja fisik yang berlebihan (Wu et al., 2020). Hal ini juga dikaitkan dengan adanya kebutuhan fisik dan psikologis, penggunaan APD, serta mengurangi penyebaran penyakit akibat paparan lama dengan pasien (Zhang et al., 2020). Dengan demikian penting bagi seorang manajer keperawatan untuk memperhatikan berbagai aspek dalam penjadwalan perawat sebagai upaya mempertahankan kesehatan dan keselamatan perawat selama masa pandemi.

Perawat manajer perlu memperhatikan lama waktu dalam setiap shift, jam kerja dalam setiap minggu, kerja lembur, shift malam, kesempatan beristirahat dan waktu istirahat. Pada masa pandemi, hal tersebut diperlukan karena dapat berdampak terhadap kinerja dan keselamatan perawat. Hasil review menunjukkan penggunaan pola shift 4-8 jam pada pagi, siang/sore dan malam dengan pembagian periode waktu dalam setiap shift (Gao et al., 2020; Apornak, 2021), dapat memberikan kemudahan bagi perawat memenuhi kebutuhan biologis dan istirahat. Pengelolaan alur kerja selama masa pandemi salah satunya adalah dengan membagi staf kedalam beberapa tim berbeda, dimana jam kerja setiap tim di ruang isolasi harus dibatasi maksimum 4 jam (Liang, 2020). Hal ini sesuai dengan satu studi lainnya bahwa fleksibilitas jadwal kerja dengan interval yang lebih pendek penting di masa pandemi (Poortaghi et al., 2021), karena beban kerja tinggi dan waktu kerja lama dapat memicu terjadinya gangguan psikologis pada perawat (Rosyanti \& Hadi, 2020). Tim harus bekerja di bangsal isolasi pada waktu berbeda, sehingga sumber daya yang memadai diperlukan.

Rasio perawat dengan jumlah pasien yang tidak seimbang di masa pandemi COVID-19 memberikan tantangan tersendiri bagi perawat manajer dalam mengelola ketenagaan di rumah sakit. Pola shift umum seperti siklus 6 hari dengan pola kerja pagi 7 jam, sore 7 jam dan malam 10 jam digunakan (Iswanto, 2020). Hal ini dikarenakan keterbatasan tenaga dan mempertimbangkan ketersediaan alat transportasi pada waktu tertentu, sehingga dengan pola shift tersebut disarankan perawat diberikan waktu istirahat dua hari setelah shift malam untuk memulihkan kondisi mereka.

Penggunaan tiga tahap rotasi dan rencana karantina selama 14 hari (Kuppuswamy \& Sharma, 2020) menjadi salah satu pilihan pola shift perawat di masa pandemi. Terdapat perbedaan lama shift seperti untuk ICU COVID-19: shift 6 jam dengan 1 jam overlapping (4 shift), ruang isolasi: shift 12 jam (2 shift), unit non-COVID-19: shift 8 jam (3 shift) hal tersebut mempertimbangkan kapasitas rumah sakit dan ketersediaan tenaga. Rencana karantina tiga tahap dengan cara kelompok pertama bertugas di ruangan isolasi selama 14 hari, kemudian dikarantina selama 14 hari di tempat akomodasi yang disediakan oleh rumah sakit; kelompok kedua masuk rotasi selama 14 hari kemudian dikarantina; kelompok ketiga masuk dan kelompok pertama bersiap kembali bertugas, selanjutnya kelompok ketiga dikarantina. Hal tersebut dilakukan untuk meningkatkan efisiensi dan memberikan cakupan yang lebih besar untuk kesehatan dan keselamatan perawat. Hal ini sesuai dengan upaya pengelolaan 
pencegahan dan pengendalian terkait pengelolaan kesehatan staf di masa pandemi, dimana saat staf garis depan termasuk perawat selesai bertugas di area isolasi dan kembali ke kehidupan normal, maka harus terlebih dahulu menjalani tes NAT untuk SARS-CoV-2. Jika hasilnya negatif, perawat harus diisolasi secara kolektif di area tertentu selama 14 hari sebelum dilepaskan dari observasi medis (Liang, 2020).

\section{SIMPULAN}

Pola shift perawat di rumah sakit pada masa pandemi COVID-19 bervariasi. Pola shift 12 jam atau 6 jam tanpa istirahat berdampak tidak baik terhadap kesehatan perawat karena dapat menyebabkan beban kerja meningkat, kelelahan, stress serta gangguan psikologis pada perawat. Adapun untuk pola shift lain cenderung memperhatikan kesehatan dan keselamatan perawat selama bertugas di masa pandemi.

\section{SARAN}

Menjaga kesehatan dan keselamatan perawat selama masa pandemi penting dilakukan, seorang perawat manajer perlu menentukan pola shift yang paling sesuai dengan kapasitas rumah sakit dan kondisi ketenagaan yang ada. Selain itu seorang perawat manajer perlu memperhatikan berbagai aspek seperti lama waktu dalam setiap shift, jam kerja dalam setiap minggu, kerja lembur, shift malam, kesempatan beristirahat dan waktu istirahat perawat sebagai upaya mempertahankan kesehatan dan keselamatan perawat selama masa pandemi.

Komunikasi antara staf dan perawat manajer terkait penjadwalan diperlukan agar tercipta suasana kerja yang kondusif dan nyaman, sehingga kinerja dan kesejahteraan perawat selama masa pandemi dapat dipertahankan.

\section{DAFTAR PUSTAKA}

Al Thobaity, A., \& Alshammari, F. (2020). Nurses on the Frontline Against the COVID-19 Pandemic: An Integrative Review. Dubai Medical Journal, 1-6. https://doi.org/10.1159/000509361

Al-Dossary, R., Alamri, M., Albaqawi, H., Al Hosis, K., Aljeldah, M., Aljohan, M., Aljohani, K., Almadani, N., Alrasheadi, B., Falatah, R., \& Almazan, J. (2020). Awareness, Attitudes, Prevention, and Perceptions of Covid-19 Outbreak Among Nurses in Saudi Arabia. International Journal of Environmental Research and Public Health, 17(21), 1-17. https://doi.org/10.3390/ijerph17218269

Andra, F., \& Insmainar, H. (2018). Produktivitas Penggunaan Waktu Kerja Perawat di Instalasi Rawat Inap Rumah Sakit Ahmad Yani Pekanbaru. Jurnal Kesmars, 1(1), 6-14. https://www.researchgate.net/publication/326386172

Apornak, A. (2021). Human Resources Allocation in the Hospital Emergency Department during COVID-19 Pandemic. International Journal of Healthcare Management, 1-7. https://doi.org/10.1080/20479700.2020.1861173

Astuti, J. T., \& Suyanto, S. (2020). Implikasi Manajemen Keperawatan dalam Penanganan Pasien Corona Virus Desease-19 (COVID-19): Literatur Review. Journal of Clinical Medicine, 7(1A), 288-297. https://doi.org/https://doi.org/10.36408/mhjcm.v7i1A.465

Dall'Ora, C., \& Dahlgren, A. (2020). Shift Work in Nursing: Closing the Knowledge Gaps and Advancing Innovation in Practice. International Journal of Nursing Studies, 112, 1-3. https://doi.org/10.1016/j.ijnurstu.2020.103743

Galehdar, N., Toulabi, T., Kamran, A., \& Heydari, H. (2021). Exploring Nurses' 
Perception of Taking Care of Patients with Coronavirus Disease (COVID-19): A Qualitative Study. Nursing Open, 8(1), 171-179. https://doi.org/10.1002/nop2.616

Gan, I. (2020). How Do Nurse Managers Describe Clinical Nurses' Work Arrangements? A Qualitative Study. Nursing Open, 7(1), 160-169. https://doi.org/10.1002/nop2.374

Gao, X., Jiang, L., Hu, Y., Li, L., \& Hou, L. (2020). Nurses' Experiences Regarding Shift Patterns in Isolation Wards during the COVID-19 Pandemic in China: A Qualitative Study. Journal of Clinical Nursing, 29(21-22), 4270-4280. https://doi.org/10.1111/jocn.15464

Holthof, N., \& Luedi, M. M. (2020). Considerations for Acute Care Staffing during a Pandemic. Best Practice and Research: Clinical Anaesthesiology, $\mathrm{xxx}(x \times x x), 1-$ 16. https://doi.org/10.1016/j.bpa.2020.12.008

Hu, D., Kong, Y., Li, W., Han, Q., Zhang, X., Zhu, L. X., Wan, S. W., Liu, Z., Shen, Q., Yang, J., He, H. G., \& Zhu, J. (2020). Frontline Nurses' Burnout, Anxiety, Depression, and Fear Statuses and Their Associated Factors during The COVID19 Outbreak in Wuhan, China: A Large-scale Cross-sectional Study. EClinicalMedicine, 24, 1-10. https://doi.org/10.1016/j.eclinm.2020.100424

Huang, L., Lin, G., Tang, L., Yu, L., \& Zhou, Z. (2020). Special Attention to Nurses' Protection during the COVID-19 Epidemic. Critical Care, 24(1), 10-12. https://doi.org/10.1186/s13054-020-2841-7

Iswanto, A. H. (2020). Innovative Work Shift for Health Workers in the Health Service Providers in Handling Covid-19 Cases. Kesmas, 15(2), 18-23. https://doi.org/10.21109/KESMAS.V15I2.3949

Joanna Briggs Institute. (2020). Critical Appraisal Tools. https://jbi.global/criticalappraisal-tools

Kluger, D. M., Aizenbud, Y., Jaffe, A., Parisi, F., Aizenbud, L., Minsky-Fenick, E., Kluger, J. M., Farhadian, S., Kluger, H. M., \& Kluger, Y. (2020). Impact of Healthcare Worker Shift Scheduling on Workforce Preservation during the COVID-19 Pandemic. Infection Control and Hospital Epidemiology, 41(12), 1443-1445. https://doi.org/10.1017/ice.2020.337

Kuppuswamy, R., \& Sharma, S. K. (2020). Efficient Utilization of Nursing Manpower during the COVID-19 Pandemic. Pondicherry Journal of Nursing, 13(2), 39-42. https://doi.org/10.5005/jp-journals-10084-12145

Liang, T. (2020). Buku Pegangan Pencegahan dan Penatalaksanaan COVID-19. pdfintl.alicdn.com

Liu, Y., Wang, H., Chen, J., Zhang, X., Yue, X., Ke, J., Wang, B., \& Peng, C. (2020). Emergency Management of Nursing Human Resources and Supplies to Respond to Coronavirus Disease 2019 Epidemic. International Journal of Nursing Sciences, 7(2), 135-138. https://doi.org/10.1016/j.ijnss.2020.03.011

Poortaghi, S., Shahmari, M., \& Ghobadi, A. (2021). Exploring Nursing Managers' Perceptions of Nursing Workforce Management during the Outbreak of COVID19: A Content Analysis Study. BMC Nursing, 20(1), 1-10. https://doi.org/10.1186/s12912-021-00546-X

Rosyanti, L., \& Hadi, I. (2020). Dampak Psikologis dalam Memberikan Perawatan dan Layanan Kesehatan Pasien COVID-19 pada Tenaga Profesional Kesehatan. Health Information: Jurnal Penelitian, 12(1), 107-130. https://doi.org/10.36990/hijp.vi.191

Suter, J., Kowalski, T., Anaya-Montes, M., Chalkley, M., Jacobs, R., \& Rodriguez- 
Santana, I. (2020). The Impact of Moving to a 12h Shift Pattern on Employee Wellbeing: A Qualitative Study in an Acute Mental Health Setting. International $\begin{array}{lllll}\text { Journal of Nursing } & \text { Studies, } & 112, & 1-9 .\end{array}$ https://doi.org/10.1016/j.ijnurstu.2020.103699

Wu, X., Zheng, S., Huang, J., Zheng, Z., Xu, M., \& Zhou, Y. (2020). Contingency Nursing Management in Designated Hospitals during COVID-19 outbreak. Annals of Global Health, 86(1), 1-5. https://doi.org/10.5334/aogh.2918

Zhang, X., Jiang, Z., Yuan, X., Wang, Y., Huang, D., Hu, R., Zhou, J., \& Chen, F. (2020). Nurses Reports of Actual Work Hours and Preferred Work Hours Per Shift among Frontline Nurses during Coronavirus Disease 2019 (COVID-19) Epidemic: A Cross-sectional Survey. International Journal of Nursing Study, 3, 17. https://doi.org/https://doi.org/10.1016/j.ijnurstu.2020.103635 